\title{
Research Article: Correlates of empowerment of farm women in agriculture through entrepreneurship development
}

\section{Priyadi Nunisa, Prasanta Mishra and Hemanta Saikia}

Article Chronicle : Received :

25.02.2019;

Revised :

05.04.2019;

Accepted :

06.05.2019

\section{KEY WoRds:}

Agriculture,

Entrepreneurship,

Economic

Empowerment, Social

empowerment,

Political

empowerment
SUMMARY : Empowerment enables women to realize their potential and power in all spheres of life. The present study was designed to through light on empowerment of farm women entrepreneurs and reveal its association with selected independent variables. The empowerment was divided into three dimensions 'economic empowerment', 'social empowerment' and 'political empowerment'. The study was conducted in Sivasagar district of Assam. A total 120 respondents has been selected. The study revealed that age, annual income, experience, self confidence, education, sources of finance, sources of borrowing and training exposure were positively and significantly related at 0.05 and 0.01 level of probability with economic empowerment. While social empowerment is positively and significantly related with annual income, self confidence, family type and training exposure at 0.05 and 0.01 level of probability and independent variables like annual income, self confidence, education and training exposure is positively and significantly related with political empowerment at 0.05 and 0.01 level of probability. The correlation co-efficient in respect of rest of the variables were found to be nonsignificant which indicated that they were not deciding factors of economic empowerment, social empowerment and political empowerment of farm women entrepreneurs.

How to cite this article : Nunisa, Priyadi, Mishra, Prasanta and Saikia, Hemanta (2019). Correlates of empowerment of farm women in agriculture through entrepreneurship development. Agric. Update, 14(2): 113117; DOI : 10.15740/HAS/AU/14.2/113-117. Copyright@ 2019: Hind Agri-Horticultural Society.
Author for correspondence :

\section{Priyadi Nunisa}

Department of Extension Education, College of Agriculture, Assam Agricultural University, Jorhat (Assam) India Email: priyadzi.nunisa@ gmail.com

See end of the article for authors' affiliations 